\title{
A Systemic Review of Clinical Trials on Dendritic-Cells Based Vaccine Against Malignant Glioma
}

\author{
Tang Chao ${ }^{1 \#, ~ W a n g ~ X i a o w e n ~}{ }^{1 \#}$, Li Zhiqi ${ }^{1}$, Yue Qi ${ }^{1}$, Yang Zixiao ${ }^{1}$, Fan Kun ${ }^{1}$, Dave SB Hoon ${ }^{2}$ and Hua Wei ${ }^{1,2 *}$
}

${ }^{1}$ Department of Neurosurgery, Huashan Hospital, Fudan University, Shanghai, China

${ }^{2}$ Department of Molecular Oncology, John Wayne Cancer Institute (JWCI), Santa Monica, California, USA

\begin{abstract}
The prognosis of patients with high grade gliomas (HGG) is quite poor, in spite of the standard combination of surgery, radiotherapy and chemotherapy. Recently, many clinical researchers have been focusing their efforts on the safety, feasibility and efficiency of dendritic cells (DCs) based vaccine against HGG. According to the literature search, 23 phase I/II clinic studies were picked and systemically reviewed to assess the application, the effect, and the future of DC vaccine for HGG. DC vaccine appears to have potential to increase overall survival with minimal complications. However, there still remains to be many challenges during vaccination, such as targeting specific/ associated antigens, adjuvants, clinical status, and the evaluation of the response.
\end{abstract}

Keywords: Glioma; Dendritic cell; Immunotherapy; Gliomas; Brain tumor

\section{Introduction}

Glioma is one of the most common primary brain tumors. High grade gliomas (HGG), such as anaplastic astrocytoma (AA), glioblastoma multiforme (GBM) have a poor prognosis with tendency to recur, even after combined treatment. Immunotherapy has been considered as the sword of Damocles hanging over cancer. The antigenspecific immunotherapy has been developed with the identification of cancer-specific antigens. Adoptive transfer of autologous antigenspecific $T$ cells might be effective but last not that long. Antigen peptide vaccination may be specific, but the tumors could develop selective immune escape. Central to the success of a vaccine is its ability to harness the potent antigen-presenting capabilities of dendritic cells (DCs), which is the most professional and powerful antigen-presenting cells. Immunotherapeutic strategies have attempted to exploit the intrinsic capacity of dendritic cells to stimulate antitumor immune effector cells, such as tumor antigen-specific cytotoxic T lymphocytes, Th1 cells, etc. (Figure 1). Since the publication of the first major clinical trial in melanoma patients in 1998 [1], therapeutic DC based vaccines have been extensively studied in numerous phase I and II trials. While advances have been encountered (especially with prostate cancer and melanoma), there are still considerable challenges that need to be addressed in future clinical trials. In this review, we describe the current methodology and highlight trials which have contributed to the development of DC vaccines. We review strategies to optimize DC vaccines in order to improve antitumor responses in patients with gliomas.

We searched on PubMed with the keywords of "glioma", "dendritic cell", "clinical trial" and "immunotherapy" to get clinical trials of DCs based immunotherapy against HGG. Finally, 23 manuscripts [2-24] on DC vaccines against HGG were found, including 2 case reports, 21 phase I/II clinic studies. All the studies were performed in a single medical center, and inclusion criteria, design, and evaluation criterion are not consistent amongst different studies. The most important issue is that the antigens for priming DCs also varied in different trials considerably, so informative meta-analysis is not possible. Here we systematically reviewed all previous clinical trials to get better understanding of DCs based immunotherapy for HGG. The safety and feasibility of DC vaccine against HGG were well illustrated, and a tendency that HGG patients could benefit from DC vaccine was observed.

\section{Application of DC Vaccine against Malignant Glioma \\ Tumor antigens}

The key of immunotherapy is tumor-specific antigen (TSA) which could ignite strong anti-tumor immune response. EGFRvIII (epidermal growth factor receptor variant III) [25] is frequently expressed on GBM (27\%) [26] and not on normal brain tissues, so it could serve as an ideal target for anti-tumor active-specific immunotherapy. This approach has already been tested by several clinical trials [27]. Many other HGG proteins such as EphA2 (Ephrin type-A receptor 2) [28] , IL-13 receptor a2 chain [29] , surviving [30], tenascin [31], and SOX2 [32] might serve as markers for gliomas. These studies need further exploration due to the limited sample size and heterogeneous expression level of glioma-specific proteins. Traditional SEREX (serological analysis of recombinant expressed cDNA clone) approach may pick up new antigens like EFTUD1 (Elongation factor Tu GTP binding domain containing protein 1) [33]. CT (cancer testis) antigen family members are also potential candidates [34], but the expression of CT antigens on glioma varies considerably. To date, it has been a big challenge to search TSA, and the lack of TSA arrests the progress of active-specific immunotherapy (Figure 2).

Genomic and proteomics profiling might offer us better information about TSA and tumor- associated antigen (TAA), and many efforts have been put on them. Kalinina $J$ et al. reviewed the proteomics screening of glioma TAA from U87 and clinical GBM samples [35]. Unfortunately, they found that not a single protein identified as a specific marker could be verified in other independent studies. The hybridoma technology, gene or antibody screening

*Corresponding author: Hua Wei, Department of Neurosurgery, Huashan hospital, Fudan University, 12 Middle Wulumuqi Road, Shanghai 200040, China, Tel: 8002626259; E-mail: hs glioma@126.com

Received January 22, 2015; Accepted April 21, 2015; Published April 27, 2015

Citation: Chao T, Xiaowen W, Zhiqi L, Qi Y, Zixiao Y, et al. (2015) A Systemic Review of Clinical Trials on Dendritic-Cells Based Vaccine Against Malignant Glioma. J Carcinogene Mutagene 6: 222. doi:10.4172/2157-2518.1000222

Copyright: (C) 2015 Chao T, et al. This is an open-access article distributed unde the terms of the Creative Commons Attribution License, which permits unrestricted use, distribution, and reproduction in any medium, provided the original author and source are credited. 
Citation: Chao T, Xiaowen W, Zhiqi L, Qi Y, Zixiao Y, et al. (2015) A Systemic Review of Clinical Trials on Dendritic-Cells Based Vaccine Against Malignant Glioma. J Carcinogene Mutagene 6: 222. doi:10.4172/2157-2518.1000222

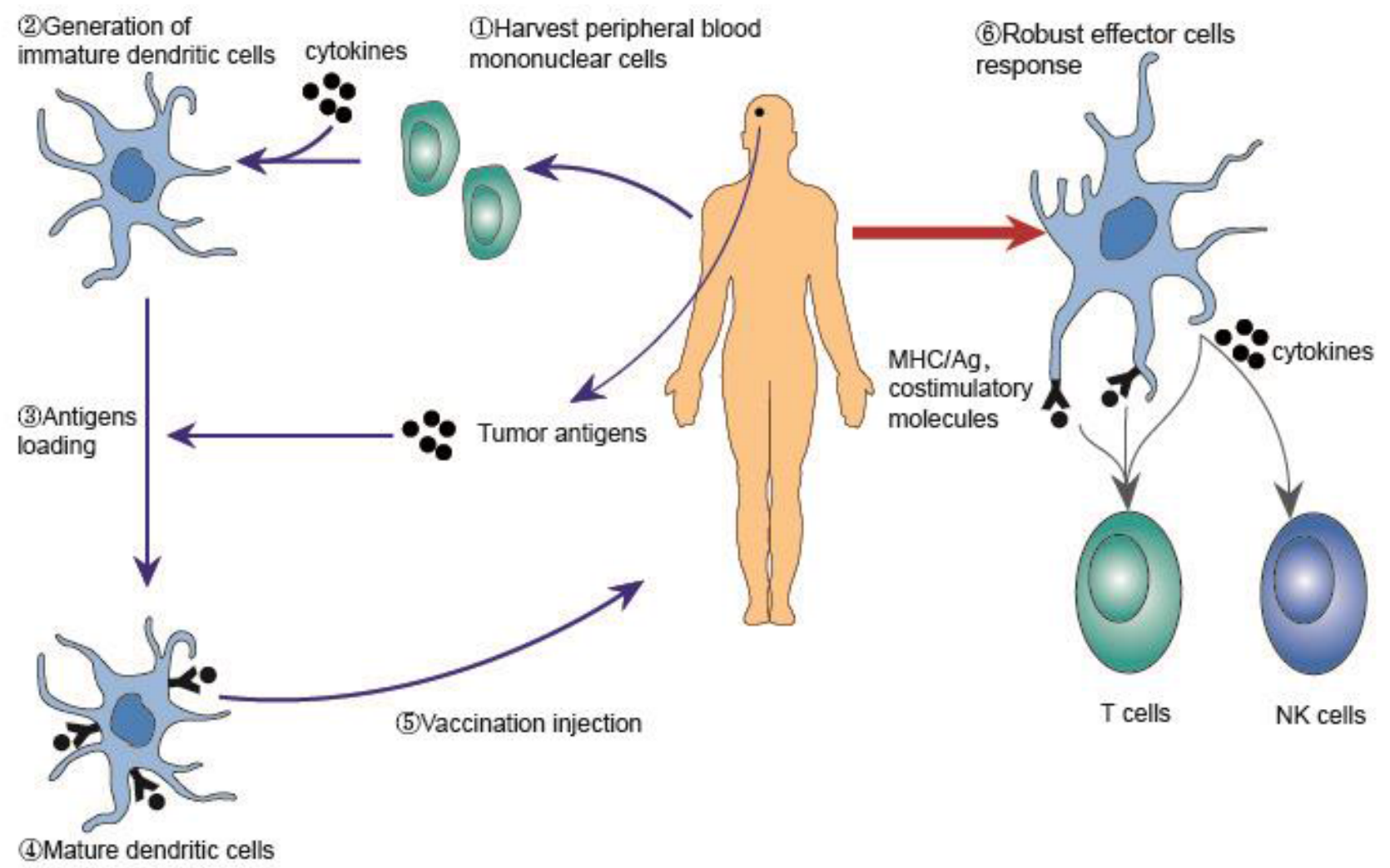

Figure 1: DCs-based immunotherapeutic strategies: (1) to harvest peripheral blood mononuclear cells, (2) to generate immature DCs with cytokine stimulation, (3) to mature DCs by loading tumor antigens, (4) to transfer activated antigen-presenting DCs back to the patients, (5) to stimulate robust anti-tumor immune effector cells such as T cells and NK cells.

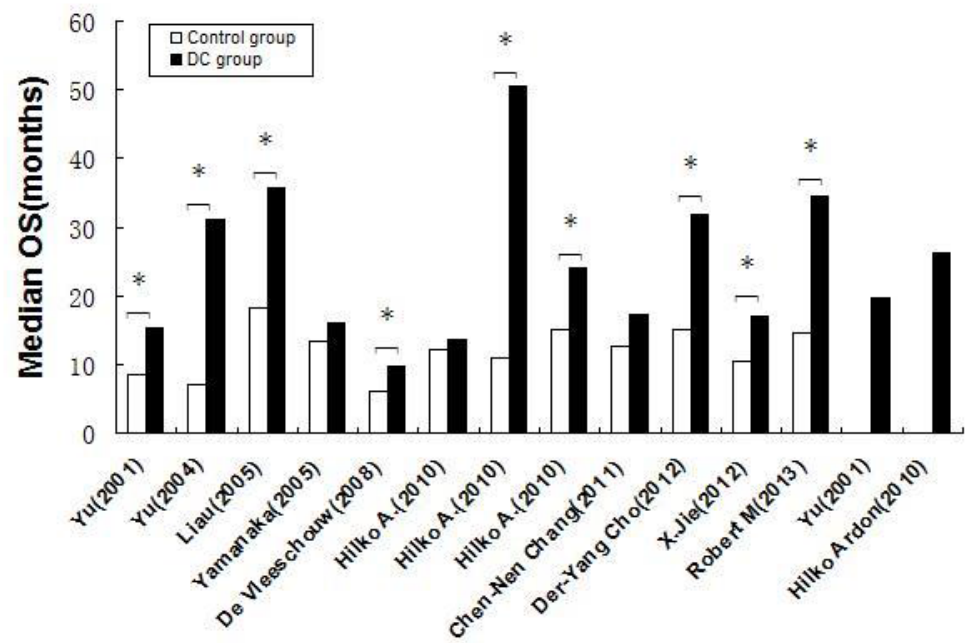

Figure 2: Summary of different DCs-based clinical trials for gliomas. Blank bar means control arm, and black bar means DCs vaccine experiment arm. *means that there is significant difference between two groups $(p<0.05)$.

technology, and predication of immunogenicity of proteins might bring us a breakthrough in TAA screening. Since single TSA/TAA proteins may have limited expression, the combination with multiple antigens could provide better target strategy in immunization. Freitas $\mathrm{M}$ et al. [36] found that CT antigen family such as ACTL8 (actin-like $8,57 \%$ ), OIP5 (Opa interacting protein 5, 54\%), XAGE3 (X antigen family, member 3, 44\%) and CTCFL (CCCTC-binding factor [zinc finger protein]-like, 15\%) were heterogeneously expressed in 48 GBM samples. Interestingly, $85 \%$ of the tumors expressed at least one of the CT antigens, and mRNA positivity for 3-4 CT antigens could serve as an independent predictor of better overall survival (OS) [36]. Okada et al mixed four TAA peptides including EphA2 (EPH Receptor A2), IL- 
13Ra2 (Interleukin 13 receptor, alpha 2), YKL-40, and gp100 to mature DCs to treat recurrent HGG patients [37]. Terasaki et al. [38] screened 14 common HLA-A24 -restricted antigens including EGFR, EZH2 (enhancer of zeste homolog 2), MRP3 (multidrug resistance-associated protein 3), Lck (lymphocyte-specific protein tyrosine kinase), SART (squamous cell carcinoma antigen recognized by T cells), etc. And then top four antigenic peptides were picked and produced in GMP laboratory serving as personalized mixed peptide vaccine and induced dose-dependent immune boosting.

The efforts have been switched to mixed total tumor antigens (TTA) [1], which could compensate the low expression of single TAA or certain antigen mutation. It would be theoretically more effective. Many clinical trials have extensively used TTA as antigen source to prime DCs [2-24]. Liau et al. used an allogenic MHC-I peptides in a case report [2], but the efficacy of this approach need large controlled study to confirm. The autologous TTA appeared to be most commonly used [3-24], many different methods were applied to isolate TTA autologous from tumor tissue lysates or cells, such as repeated freezing and thaw lysates $[5,8,11,12,16,18], \mathrm{X}$-ray irradiation $[3,10,14,24]$ acid elution [13]. Autologous tumor specific peptides [4] or RNA [7] was also used. These studies all reported minimal risk of toxicity or side effects and improved survival. The main concern about TTA is still its low immunogenicity, whereby various techniques have been explored to improve it. The fusion of DC and tumor cells with PEG (Poly Ethylene Glycol) was explored [39]. Prahlad P et al. compared DCs primed with different tumor lysates, RNA, and apoptotic cells, and DC primed with apoptotic cells seemed to have the optimal immune response [40]. The progress in stem cell research encouraged researchers $[41,42]$ to employ tumor stem cells (TSCs) for antigens preparation. The mixed TTA antigens from TSCs show better effect in vitro and in vivo studies against GBM. We have further sorted CD133 positive TSCs to produce TTA, and have achieved even better responses in vitro [42]. Phase I clinical trials with DCs primed with TTA from TSCs against GBM are ongoing [20]. Antigens derived from tumor exosome [43] or autophagosome [44] have been explored also. These potential strategies may be useful in specific active immunotherapy.

It is quite important to choose the most efficient antigens. However, all of the results to date have shown that each antigen has its own shortcomings. For example, EGFRvIII vaccine only could be applied to the patients with EGFRvIII variant. For TAA, it is unclear which of the antigens will benefit the patients, so, further refinement of TAA is necessary. Another important clinical issue is the isolation of sufficient TAA or TTA, since it usually requires a significant amount of tissue or cells to process.

\section{Dendritic cells preparation}

DCs could be derived from peripheral blood or bone marrow. Peripheral blood mononuclear cells (PBMCs) are the main source to generate DCs with stimulation of GM-CSF and IL-4 [45]. TNF- $\alpha$ and IL- $1 \beta$ were added by some investigators before DC maturation [46], and IL- $1 \beta$, TNF- $\alpha$, IFN- $\alpha$ and IFN- $\beta$ were applied to generate $\alpha \mathrm{DC} 1$ which could initiate more effective anti-tumor immune response by Okada et al. [14,47]. For patients without sufficient tumor tissues for tumor antigens, transfection with mRNA or DNA into DCs to express more cytokines and co-stimulatory molecules might be feasible [48].

After maturation, DC vaccine could be delivered subcutaneously or intramuscularly. However, the post-injective lymphatic return rate (LRR) is always limited. So, ultrasound-guided intranodal injection [37] and injection through Ommaya reservoir connected to tumor area or ventricles was also tried $[12,49,50]$. No evidence demonstrated any significant effect or more severe complications like edema after the administration of DCs. Although there is no criterion for the course of vaccine, it was deemed that both low quantity and limited dosages were likely to limit DCs' effect [51]. As shown in the Table 1, DCs were delivered every 1-2 weeks for more than 3 times in most studies [2-24].

\section{Combination with adjuvants or other therapies}

Not only the tumor antigen, but also the specific adjuvant, and combination with other therapies as well, should be considered during the design and evaluation of tumor vaccine. Bacillus Calmette Guerin (BCG) and Freund's adjuvant were used as adjuvants traditionally. More new effective and targeted adjuvants, such as cytokines (IL-12), MF59, cholera toxin B subunit (CTB), AS04 and Toll-like receptor agonist (CpG oligonucleotides, Imiquimod and poly I:C), have demonstrated some efficiency and safety [52]. Development of adjuvants has been a major issue in tumor vaccine strategy to improve immunogenicity. The main concern is that there are no effective universal adjuvants for tumor immunization protocols. Adjuvants can enhance specific type of immune responses albeit cellular or humoral of poorly immunogenic antigens. Emerging evidence from clinical trials indicates that DCs could elicit cellular immune reponse [53], induce tumor-specfic cytotoxic $\mathrm{T}$ cells and also enhance natural-killer cell immunity [54] Therefore adjuvants that can boost specific type of cell- mediated vaccine responses would be more helpful. This may also require temporal events that reflect tumor status and vaccine effectiveness during the course of immunotherapy.

Chemotherapy and radiotherapy are the main adjuvant treatment modalities for HGG after surgical resection. Prins et al. [55] reported that immunotherapy has good synergism with chemotherapy and radiotherapy, and have speculated that apoptotic tumor cells after adjuvant therapies might provide abundant tumor antigens to DCs. Another study by Hilko Ardon [18] found the CD8+T cells could increase significantly in GBM after treatment with the combo of DC vaccine and temozomide. As for the time frame to administrate DC vaccines, Walker [24] and Chang [19] recommended vaccine first, since ionizing radiation will not only kill the tumor cells, but also may impair the immune responses.

\section{Evaluation of curative effect}

No standard has been proposed to assess the effect of DC vaccine. OS and progression free survival (PFS) are often adopted to evaluate the effect. Interestingly, OS seems to have more chance to be prolonged by vaccine than PFS. Age, tumor invasiveness status and the extent of tumor resection have been proven to be independent prognostic predictors [15]. The bias of selection of patients with potential good prognosis will significantly sway the survival time. Maximal tumor resection still dominates other considerations, and obviously DC vaccines are inept to big tumor burdens. So the strategy is to remove all clinically evident tumor, and then to vaccinate to inhibit subclinical micro-metastatic disease. Some immune index might provide us some reference to select patients or to predict the response as previously discussed.

In the reviewed 23 phase I/II clinical trials (Table 1), 13 studies with OS data available were further analyzed, and DCs vaccine seems effective on the improvement of OS (Figure 1). Yu et al. [4,11] reported two trials consecutively, and the median OS of GBM patients received DCs vaccine primed with acid-eluted tumor peptides was much longer than the control patients. In the clinical trials by Liau et al. [13] and Hilko et al. $[17,18]$, the improvement of OS in pediatric patients with 
Citation: Chao T, Xiaowen W, Zhiqi L, Qi Y, Zixiao Y, et al. (2015) A Systemic Review of Clinical Trials on Dendritic-Cells Based Vaccine Against Malignant Glioma. J Carcinogene Mutagene 6: 222. doi:10.4172/2157-2518.1000222

\begin{tabular}{|c|c|c|c|c|c|c|c|c|}
\hline Citation & Study type & Case & DC-vaccine treated & Antigen source & Culture of DC & Dosage & $\begin{array}{l}\text { Immunological } \\
\text { reaction }\end{array}$ & Clinical response \\
\hline [2] & Case report & 1 & R-GBM & $\begin{array}{l}\text { allogeneic MHC-I } \\
\text { GBM peptides }\end{array}$ & GM-CSF and IL-4; & i.d. $1 / 2$ wks $(\times 3)$ & Increased TILs & PD, OS:21m \\
\hline [4] & Phase I & 9 & $\begin{array}{l}\text { N-GBM }(n=7) \\
A A(n=2)\end{array}$ & $\begin{array}{l}\text { autologous tumor } \\
\text { specific, MHC-I }\end{array}$ & GM-CSF and IL-4; & s.c. $1 / 2$ wks $(\times 3)$ & $\begin{array}{l}\text { SCR, TILs (CTL } \\
\text { and Tm) }\end{array}$ & Med OS; 455d \\
\hline [3] & Phase I & 8 & $\operatorname{GBM}(n=5), A A(n=3)$ & ATC & $\begin{array}{l}\text { GM-CSF, IL-4 and } \\
\text { TNF- } \alpha\end{array}$ & i.d. $1 / 3$ wks $(\times 9)$ & $\begin{array}{l}\text { Increased NK cells, } \\
\text { IFN-y }\end{array}$ & $\operatorname{PR}(n=2) ; S D(n=4) ; P D(n=2)$ \\
\hline [6] & Phase I/II & 10 & $\operatorname{GBM}(n=7), A A(n=3)$ & ATL & GM-CSF and IL-4 & $\begin{array}{l}\text { i.d. and/or i.t. } \\
\text { (ommaya) } 1 / 3 \text { wks } \\
(\times 10)\end{array}$ & $\begin{array}{l}\text { Increased NK cells; } \\
\text { DTH+; infiltration of } \\
\text { T cells }\end{array}$ & - \\
\hline [5] & Phase I/II & 17 & N-GBM, R-GBM & ATL & GM-CSF and IL-4; 3 & $\begin{array}{l}\text { s.c. } 1 / 2 \text { wks }(\times 3)+1 \\
\text { at } 6^{\text {th }} \text { wks }\end{array}$ & Increased IFN- $Y$ & -- \\
\hline [11] & Phase I/II & 14 & $\begin{array}{l}N-G B M(n=1) \text { and } A A \\
(n=1) ; R-G B M(n=9) \\
\text { and } A A(n=3)\end{array}$ & ATL & CM-CSF and IL-4 & s.c. $1 / 2$ wks $(\times 3)$ & $\begin{array}{l}\text { Increased IFN-Y } \\
\text { mRNA }\end{array}$ & Med OS; 133 wks \\
\hline [7] & Phase I & 7 & $\begin{array}{l}\text { EM }(n=3) ; \operatorname{GBM}(N=2) ; \\
\operatorname{AA}(n=1) ; \operatorname{PA}(n=1) ; \\
M B(n=1) ; \operatorname{PXAs}(n=1)\end{array}$ & Tumor tissue RNA & GM-CSF and IL-4 & $\begin{array}{l}\text { i.v. and i.d. } \\
1 / 2 \text { wks } \times 2+1 / 1 \mathrm{mth} \\
(\times 5)\end{array}$ & - & - \\
\hline [9] & Case report & 1 & AA & ATL & $\begin{array}{l}\text { GM-CSF and IL-4; } \\
\text { TNF- } \alpha, \text { IL-1 } \beta \text {, and } \\
\text { PGE2 }\end{array}$ & $\begin{array}{l}\text { i.d. } 1 / 2 \text { wks }(\times 2)+1 / 1 \\
\text { mth }(\times 6)\end{array}$ & $\mathrm{DTH}(+)$ & PFS(60m) \\
\hline [8] & Phase I & 12 & $\begin{array}{l}\text { HGG } \\
(n=8), A A(n=4)\end{array}$ & ATL & $\begin{array}{l}\text { GM-CSF and IL-4; } \\
\text { TNF- } \alpha, \text { IL-1 } \beta \text {, and } \\
\text { PGE2 }\end{array}$ & $\begin{array}{l}\text { i.d. } 1 \text { at } 1^{\text {st }} w+2 \text { at } \\
2^{\text {nd }}+1 / 1 \text { mth }\end{array}$ & $\mathrm{DTH}(+)$ & $\begin{array}{l}\mathrm{CCR}(1), \mathrm{NC}(3), \mathrm{PD}(3) \\
\text { Med OS: } 42.0 \text { wks }\end{array}$ \\
\hline [10] & Phase I/II & 15 & $\operatorname{GBM}(n=6) ; A A(n=9)$ & ATC & $\begin{array}{l}\text { FCs and rhIL-12 } \\
\text { GM-CSF, IL-4, } \\
\text { and TNF- } \alpha \text {; }\end{array}$ & i.d, s.c. $1 / 2$ wks $(\times 6)$ & increased IFN- $\gamma$, & $\operatorname{PR}(1), M R(1), N C(1), P D(3)$ \\
\hline [13] & Phase I & 12 & $\begin{array}{l}\text { N-GBM }(n=7) \\
\text { R-GBM }(n=5)\end{array}$ & $\begin{array}{l}\text { Acid-eluted } \\
\text { ATCP }\end{array}$ & GM-CSF and IL-4 & i.d. $1 / 2-4$ wks $(\times 3)$ & $\begin{array}{l}\text { Tumor specific } \\
\text { CTL; }\end{array}$ & $\begin{array}{l}\text { Med PFS: } 15.5 \mathrm{~m} \\
\text { Med OS: } 23.4 \mathrm{~m}\end{array}$ \\
\hline [12] & Phase/ II & 24 & $\begin{array}{l}\text { R-AA }(n=6) \\
\operatorname{GBM}(n=18)\end{array}$ & ATL & $\begin{array}{l}\text { GM-CSF and IL-4; } \\
\text { OK-432 }\end{array}$ & $\begin{array}{l}\text { i.d. or i.d. combined } \\
\text { i.t. (ommaya) } 1 / 3 \text { wks }\end{array}$ & $\begin{array}{l}\text { DTH(+); increased } \\
\text { tumor specific CTLs }\end{array}$ & $\begin{array}{l}\text { Med OS 480d; PR(1), MR(3), } \\
\text { NC(6), PD(8) }\end{array}$ \\
\hline$[14]$ & Phase I & 7 & R-GBM ; AA & $\begin{array}{l}\text { irradiated ATC } \\
\text { and TFG-IL4-Neo- } \\
\text { TK-transfected } \\
\text { fibroblast }\end{array}$ & $\begin{array}{l}\text { UPCI95-033 } \\
\text { UPCI 99-111 }\end{array}$ & $\begin{array}{l}\text { i.d. } 1 \text { st in } D 1+2^{\text {nd }} \\
\text { in } D 7 \\
+1 / 2 \text { wks }\end{array}$ & $\begin{array}{l}\text { CD4+, CD8+ IFN-y } \\
\text { against } \\
\text { EphA2883-89; } \\
\text { HLA-A2 }\end{array}$ & $\begin{array}{l}\text { UPCI95033: Stable disease } \\
\text { 4m }(n=2) \text { UPCI99-111: } \\
\text { Med PFS } 6 m\end{array}$ \\
\hline [16] & Phase II & 34 & $\begin{array}{l}\text { N-GBM }(n=11) \\
\operatorname{R-GBM}(n=23)\end{array}$ & ATL & GM-CSF and IL-4 & $\begin{array}{l}\text { s.c. } 1 / 2 \text { wks }(\times 3)+1^{\text {st }} \\
\text { wk\#6 }\end{array}$ & increased IFN- $y$ & $\begin{array}{l}\text { N-GBM OS: } 642 \pm 61 d \text {; PFS: } \\
308 \pm 55 d \text {; R-GBM OS: } 599 \\
\pm 75 \text { d; PFS: } 401 \pm 53 d\end{array}$ \\
\hline [24] & Phase I & 13 & $\begin{array}{l}\mathrm{GBM}(n=9) \text { and } \\
\mathrm{AA}(\mathrm{n}=4)\end{array}$ & ATC & GM-CSF and IL-4 & $\begin{array}{l}\text { i.d. } 1 / 2 \text { wks }(\times 6)+1 / 6 \\
\text { wks }\end{array}$ & $\begin{array}{l}\text { Increased T cell } \\
\text { infiltration }\end{array}$ & Med OS: $11 \mathrm{~m}$ \\
\hline [15] & Phase/ II & 56 & R-GBM & ATL & $\begin{array}{l}\text { GM-CSF and IL-4; } \\
\text { TNF- } \alpha, \text { IL-1 } \beta \text {, and } \\
\text { PGE2 }\end{array}$ & $\begin{array}{l}\text { i.d. G1: } 1^{\text {st }}, 1 \mathrm{w}, 2^{\text {nd }}, 3 \\
\text { w, } 1 / 4 \text { wks; G2: } 1 / 2 \text { wks } \\
(\times 5), 1 / 4 \text { w; G3: } 1 / 1 \\
\text { w }(\times 4)\end{array}$ & $\mathrm{DTH}(+)$ & Med PFS 3m; OS, 9.6m. \\
\hline [17] & Phase/ II & 45 & $\begin{array}{l}\operatorname{HGG}(n=33), M B / \\
\operatorname{PNET}(n=5), E M(n=4) \\
\text { and ATRT }(n=3)\end{array}$ & ATL & GM-CSF and IL-4 & $\begin{array}{l}\text { i.d. G1: } 1^{\text {st }}, 1 \text { w, } 2^{\text {nd }} \\
3 \text { w, } 1 / 4 \text { w; G2: } 1 / 2 \text { w } \\
(\times 5), 1 / 4 \text { w; G3: } 1 / 1 \\
\text { w }(\times 4), \text { ATL; G4: } 1 / 1 \\
\text { w }(\times 4)\end{array}$ & - & HGG: Med OS 13.5m \\
\hline [18] & Phase/ II & 8 & N-GBM & ATL & $\begin{array}{l}\text { GM-CSF and IL-4; } \\
\text { TNF- } \alpha, \text { IL-1 } \beta \text {, and } \\
\text { PGE2 }\end{array}$ & $\begin{array}{l}\text { i.d. } 1 / 1 \mathrm{w}(\times 4)+1 / 2 \\
\text { wks }(\operatorname{vacc}+\mathrm{ATL})\end{array}$ & $\begin{array}{l}\text { increased } \\
\text { CD8+CD25+cell, } \\
\text { T-cell IFN-y }\end{array}$ & Med OS: $24 \mathrm{~m}$; PFS: $18 \mathrm{~m}$ \\
\hline [19] & $\begin{array}{l}\text { Phase } \\
\text { I/II }\end{array}$ & 17 & $\begin{array}{l}\text { N-GBM, AA and } \\
\text { R-GBM, AA }\end{array}$ & ATL & INF-Y & $\begin{array}{l}\text { S.C } 1 / 1 \text { wks }(\times 4)+1 / 2 \\
\text { wks }(\times 2)+1 / 2 \text { mth } \\
(\times 4)\end{array}$ & Increased TIL & GBM:Med:OS 520d \\
\hline [42] & Phase I & 5 & R-HGG & $\begin{array}{l}\text { Stem-like associate } \\
\text { antigen }\end{array}$ & GM-CSF and IL-4 & $\begin{array}{l}1 / 2 \mathrm{w}(\times 3)+\text { poly- } \\
\mathrm{ICICI} \mathrm{M} 1 / 2 \text { wks }\end{array}$ & - & - \\
\hline [21] & $\begin{array}{l}\text { RCT } \\
\text { Phase II }\end{array}$ & 34 & N- GBM and R- GBM & ATL & GM-CSF and IL-4 & $\begin{array}{l}\text { s.c. } 1 / 1 \text { w }(\times 4)+1 / 2 \\
\text { wks }(\times 2)+1 / 4 \text { wks } \\
(\times 4)\end{array}$ & - & $\begin{array}{l}\text { Med OS: } 31.9 \mathrm{~m} ; \\
\text { Med PFS: } 8.5 \mathrm{~m}\end{array}$ \\
\hline [22] & Phase II & 25 & N-and R- GBM & $\begin{array}{l}\text { ATC antigen by } \\
\text { heat-shock }\end{array}$ & GM-CSF and IL-4 & $\begin{array}{l}\text { i.d. } 1^{\text {st }} \text { in } D 7+2^{\text {nd }} \text { in } \\
\text { D14+3 } \\
\text { in } D 42\end{array}$ & - & Med OS: $17 \mathrm{~m}$ \\
\hline [23] & Phase I & 34 & $\operatorname{GBM}(27)$ and $\mathrm{AA}(7)$ & ATL, GAA & GM-CSF and IL-4 & $1 / 2 \mathrm{wks}+1 / 3 \mathrm{mth}$ & $\begin{array}{l}\text { Lymphocyte subset } \\
\text { change }\end{array}$ & $\begin{array}{l}\text { ATL/GAA; Med OS } \\
34.4 \mathrm{~m} / 15.5 \mathrm{~m}\end{array}$ \\
\hline
\end{tabular}

Abbreviations: R-GBM: Recurrent GBM; GBM: Gliobastoma Multiforme; I.D.: Intradermally; Wks: Weeks; PD: Progressive Disease; OS: Overall Survival; N-GBM: Newly Diagnosed GBM; AA: Anaplastic Astrocytoma; S.C.: Subcutaneously; Med: Media; ATC: Autologous Tumor Cell; PR: Partial Response; SD: Stable Disease; PD: Progressive Disease; ATL: Autologous Tumor Lysate; EM: Ependymoma; PA: Pilocytic Astrocytoma; MB: Medulloblastoma; PXA: Pleomorphic Xanthoastrocytoma; I.V.: Intravenously; Mth: Months; PFS: Progression Free Survival; HGG: High Grade Gliomas; CCR: Continued Complete Remission; NC: No Change; MR: Mixed Response; ATCP: Autologous Tumor Cell Peptide; PNET: Primitive Neuroectodermal Tumors; GAA: Glioma Associated Antigen.

Table 1: Characteristics of clinical trials against gliomas using DCs based vaccine immunotherapy. 
HGG treated with DCs vaccine was not observed, while an effective responses with an significant increase of OS was observed in adult patients. The longest follow-up was reported by Chang [19], and the survival rate after five years were $18.8 \%$ for newly diagnosed HGG. The only RCT (Randomized Clinical Trial) was performed by Der-Yang Cho et al. [21], and the results showed that the vaccinated patients got an impressive improvement of OS. However, in this RCT study, most patients in the experiment arm received salvage therapy. As a group, the numbers of enrolled patients and RCT studies were so limited, phase II/III RCT and long-term evaluation are urgently needed. Overall, DCs based vaccine appears to benefit certain HGG patients (Figure 1).

As for the immunological index, tumor infiltrating lymphocytes (TILs) is one objective indicator, which has been verified in several clinical trials $[2,4,14,19,24]$. Delayed type hypersensitivity (DTH) were observed in a number of clinical trials $[6,8,9,12,15]$. Wheeler et al found that the PFS and OS of the patients with the elevation of IFN- $\gamma$ (more than 1.5 times in serum) were longer than those without IFN- $\gamma$ elevation after vaccination [16]. Other factors such as the dosage of vaccine, regulatory $\mathrm{T}$ cells, the ratio of $\mathrm{Th} 1 / \mathrm{Th} 2$ showed no correlations with the prognosis $[24,55]$. Yu et al. used the MAGE-1 (melanoma antigen family A-1) specific CTLs as a marker to address the antigenspecific immune response of the patients [11].

\section{Evaluation of side effect}

DC vaccine for HGG seems to be well tolerated across all variations in all clinical trials. The adverse events associated with immunotherapy were evaluated by the RECSIT (new Response Evaluation Criteria in Solid Tumors). Skin itch, erythema on the injection location, headache, fever, and lymphopenia were observed in some cases. Notably, seizure were found in two studies with a frequency of $16.6 \%$ [19] and $8.3 \%$ [13]. Since there is no comparison with other treatment modalities, no statistical analysis or definite conclusion could be drawn. By and large, no evidence of toxicity or severe side effect was observed.

\section{Challenge of HGG immune escape}

GBM themselves could develop various immunosuppressive methods to circumvent surveillance which lead to the failure of immunotherapy. Like other malignant tumors, GBM cells could express less MHC or tumor antigens to reduce the first signal. In the meantime, GBM might cut down co-stimulatory molecules like CD80, CD86, CD40, LFA-1(lymphocyte function associated antigen-1), and ICAM1 (intercellular cell adhesion molecule-1) [56] or express negative regulators such as PDL- 1 (programmed cell death ligand 1 ), TGF- $\beta$, IL-10, FASL(Fas ligand ) [57], and B7 family members such as B7H4 [58]. All these factors can hamper the activation of T cells and NK cells, thus impede the antitumor effect. The subpopulation of TSCs in glioma are the only cells able to generate tumors in immune compromised hosts, and TSCs can better escape from the immune attack than nonstem cells do [57]. TSCs in glioma have been shown to be immune privileged, making immunotherapy more challenging. Accordingly, the translation of DC-induced antitumor immunity into clinical activity needs to overcome the GBM-associated immunosuppression, blockade of negative co-stimulatory molecules, and immunotherapy targeted TSCs might improve the antitumor effect.

Besides the tumor ability of immune escape, microenvironment or niche in the GBM tumor mass make matters even more complicated. Pellegatta S et al. used GL261 cells with good immunogenicity to generate brain tumors in C57BL6 mice. Interestingly intratumoral and subcutaneous injection with DCs could ignite stronger immune response than subcutaneous injection only, and then prolong the survival of GL261 beard mice [50]. This indicated that brain tumors may have their unique niche which is different from other solid tumors. Many immune suppressive lymphocytes such as Treg [59], MDSC (myeloid-derived suppressor cells) [60], M2 microglia [61] have been reported to be recruited to GBM to suppress the local immune system, and even favor the tumor growth. Other FAP+ stromal cells might also contribute to the immunosuppressive microenvironment [62]. Some factors including IL-6 [63], CSF-1(colony stimulating factor 1) [64], and TGF- $\beta$ [65] are secreted into tumor niche, and they also played an important role in the "cross-talk" between tumor cells and host immune system.

As tumor vaccination studies continue, many new approaches of tumor immunization strategies have come about such as use of PD-1 (programmed death receptor-1). HGG was considered to have better immunogenicity, and then have better response to immunotherapy. Prin et al. showed that patients with mesenchymal GBM were more sensitive to immunotherapy according to the gene analysis [24]. However, Okada et al reported that low grade gliomas also have a good response to DC vaccine [66].

\section{Conclusion}

DCs based immunotherapy might improve the overall survival of HGG, and could serve as a novel treatment modality. However, the design of the tumor antigens, administration of DCs, and the prediction of the response need more progress. Although, many of the phase II studies have been promising, there are still considerable challenges that need to be addressed. Larger phase II and III immunotherapy trials are warranted to confirm the effectiveness. The other important factor to be determined is which patients will best benefit vaccine therapy and disease outcome expected.

\section{Acknowledgments}

This work was supported by International S\&T Cooperation Program of China 2014DFA31470, the China National Natural Science Foundation (81001115), and China National Funds for Distinguished Young Scientists (81025013), Ruth Weil family foundation.

\section{References}

1. Nestle FO, Alijagic S, Gilliet M, Sun Y, Grabbe S, et al. (1998) Vaccination of melanoma patients with peptide- or tumor lysate-pulsed dendritic cells. Nat Med 4: 328-332

2. Liau LM, Black KL, Martin NA, Sykes SN, Bronstein JM, et al. (2000) Treatment of a patient by vaccination with autologous dendritic cells pulsed with allogeneic major histocompatibility complex class I-matched tumor peptides. Case Report. Neurosurg Focus 9: e8.

3. Kikuchi T, Akasaki Y, Irie M, Homma S, Abe T, et al. (2001) Results of a phase clinical trial of vaccination of glioma patients with fusions of dendritic and glioma cells. Cancer Immunol Immunother 50: 337-344.

4. Yu JS, Wheeler CJ, Zeltzer PM, Ying H, Finger DN, et al. (2001) Vaccination of malignant glioma patients with peptide-pulsed dendritic cells elicits systemic cytotoxicity and intracranial T-cell infiltration. Cancer Res 61: 842-847.

5. Wheeler CJ, Black KL, Liu G, Ying H, Yu JS, et al. (2003) Thymic CD8+ T cell production strongly influences tumor antigen recognition and age-dependent glioma mortality. J Immunol 171: 4927-4933.

6. Yamanaka R, Abe T, Yajima N, Tsuchiya N, Homma J, et al. (2003) Vaccination of recurrent glioma patients with tumour lysate-pulsed dendritic cells elicits immune responses: results of a clinical phase I/II trial. $\mathrm{Br} \mathrm{J}$ Cancer 89: 1172 1179 .

7. Caruso DA, Orme LM, Neale AM, Radcliff FJ, Amor GM, et al. (2004) Results of a phase 1 study utilizing monocyte-derived dendritic cells pulsed with tumo RNA in children and young adults with brain cancer. Neuro Oncol 6: 236-246. 
8. Rutkowski S, De Vleeschouwer S, Kaempgen E, Wolff JE, Kühl J, et al. (2004) Surgery and adjuvant dendritic cell-based tumour vaccination for patients with relapsed malignant glioma, a feasibility study. Br J Cancer 91: 1656-1662.

9. De Vleeschouwer S, Van Calenbergh F, Demaerel P, Flamen P, Rutkowski S, et al. (2004) Transient local response and persistent tumor control in a child with recurrent malignant glioma: treatment with combination therapy including dendritic cell therapy. Case report. J Neurosurg 100: 492-497.

10. Kikuchi T, Akasaki Y, Abe T, Fukuda T, Saotome H, et al. (2004) Vaccination of glioma patients with fusions of dendritic and glioma cells and recombinant human interleukin 12. J Immunother 27: 452-459.

11. Yu JS, Liu G, Ying H, Yong WH, Black KL, et al. (2004) Vaccination with tumor lysate-pulsed dendritic cells elicits antigen-specific, cytotoxic T-cells in patients with malignant glioma. Cancer Res 64: 4973-4979.

12. Yamanaka R, Homma J, Yajima N, Tsuchiya N, Sano M, et al. (2005) Clinical evaluation of dendritic cell vaccination for patients with recurrent glioma: results of a clinical phase I/II trial. Clin Cancer Res 11: 4160-4167.

13. Liau LM, Prins RM, Kiertscher SM, Odesa SK, Kremen TJ, et al. (2005) Dendritic cell vaccination in glioblastoma patients induces systemic and intracranial T-cell responses modulated by the local central nervous system tumor microenvironment. Clin Cancer Res 11: 5515-5525.

14. Okada H, Lieberman FS, Walter KA, Lunsford LD, Kondziolka DS, et al. (2007) Autologous glioma cell vaccine admixed with interleukin-4 gene transfected fibroblasts in the treatment of patients with malignant gliomas. J Transl Med 5: 67.

15. De Vleeschouwer S, Fieuws S, Rutkowski S, Van Calenbergh F, Van Loon J et al. (2008) Postoperative adjuvant dendritic cell-based immunotherapy in patients with relapsed glioblastoma multiforme. Clin Cancer Res 14: 3098 3104.

16. Wheeler CJ, Black KL, Liu G, Mazer M, Zhang XX, et al. (2008) Vaccination elicits correlated immune and clinical responses in glioblastoma multiforme patients. Cancer Res 68: 5955-5964.

17. Ardon H, De Vleeschouwer S, Van Calenbergh F, Claes L, Kramm CM, et al. (2010) Adjuvant dendritic cell-based tumour vaccination for children with malignant brain tumours. Pediatr Blood Cancer 54: 519-525.

18. Ardon H, Van Gool S, Lopes IS, Maes W, Sciot R, et al. (2010) Integration of autologous dendritic cell-based immunotherapy in the primary treatment for patients with newly diagnosed glioblastoma multiforme: a pilot study. $J$ Neurooncol 99: 261-272.

19. Chang CN, Huang YC, Yang DM, Kikuta K, Wei KJ, et al. (2011) A phase I/I clinical trial investigating the adverse and therapeutic effects of a postoperative autologous dendritic cell tumor vaccine in patients with malignant glioma. J Clin Neurosci 18: 1048-54.

20. Hua WYY, Yi-wei CZP, Ying MZL (2011) Phase I study of dendritic cells pulsed with tumor stem-like cells associated antigens against malignant glioma in recurrent patients. Chin J Neurosurg 27: 90.

21. Cho DY, Yang WK, Lee HC, Hsu DM, Lin HL, et al. (2012) Adjuvan immunotherapy with whole-cell lysate dendritic cells vaccine for glioblastoma multiforme: a phase II clinical trial. World Neurosurg 77: 736-744.

22. Jie X, Hua L, Jiang W, Feng F, Feng G, et al. (2012) Clinical application of a dendritic cell vaccine raised against heat-shocked glioblastoma. Cell Biochem Biophys 62: 91-99.

23. Prins RM, Wang X, Soto H, Young E, Lisiero DN, et al. (2013) Comparison of glioma-associated antigen peptide-loaded versus autologous tumor lysateloaded dendritic cell vaccination in malignant glioma patients. J Immunother 36: 152-157

24. Walker DG, Laherty R, Tomlinson FH, Chuah T, Schmidt C (2008) Results of a phase I dendritic cell vaccine trial for malignant astrocytoma: potential interaction with adjuvant chemotherapy. J Clin Neurosci 15: 114-121.

25. Sampson JH, Archer GE, Mitchell DA, Heimberger AB, Herndon JE 2nd, et al (2009) An epidermal growth factor receptor variant III-targeted vaccine is safe and immunogenic in patients with glioblastoma multiforme. Mol Cancer Ther 8: $2773-2779$.

26. Yoshimoto K, Dang J, Zhu S, Nathanson D, Huang T, et al. (2008) Development of a real-time RT-PCR assay for detecting EGFRvill in glioblastoma samples. Clin Cancer Res 14: 488-493.

27. Heimberger AB, Crotty LE, Archer GE, Hess KR, Wikstrand CJ, et al. (2003)
Epidermal growth factor receptor VIII peptide vaccination is efficacious agains established intracerebral tumors. Clin Cancer Res 9: 4247-4254.

28. Chow KK, Naik S, Kakarla S, Brawley VS, Shaffer DR, et al. (2013) T cells redirected to EphA2 for the immunotherapy of glioblastoma. Mol Ther 21: 629 637

29. Okano F, Storkus WJ, Chambers WH, Pollack IF, Okada H (2002) Identification of a novel HLA-A*0201-restricted, cytotoxic T lymphocyte epitope in a human glioma-associated antigen, interleukin 13 receptor alpha2 chain. Clin Cancer Res 8: 2851-2855.

30. Yamada Y, Kuroiwa T, Nakagawa T, Kajimoto Y, Dohi T, et al. (2003) Transcriptional expression of survivin and its splice variants in brain tumors in humans. J Neurosurg 99: 738-745.

31. McLendon RE, Wikstrand CJ, Matthews MR, Al-Baradei R, Bigner SH, et al. (2000) Glioma-associated antigen expression in oligodendroglial neoplasms. Tenascin and epidermal growth factor receptor. J Histochem Cytochem 48 1103-1110.

32. Schmitz M, Temme A, Senner V, Ebner R, Schwind S, et al. (2007) Identification of SOX2 as a novel glioma-associated antigen and potential target for T cellbased immunotherapy. Br J Cancer 96: 1293-1301.

33. Saito K, lizuka Y, Ohta S, Takahashi S, Nakamura K, et al. (2014) Functional analysis of a novel glioma antigen, EFTUD1. Neuro Oncol 16: 1618-1629.

34. Chi DD, Merchant RE, Rand R, Conrad AJ, Garrison D, et al. (1997) Molecula detection of tumor-associated antigens shared by human cutaneous melanomas and gliomas. Am J Pathol 150: 2143-2152.

35. Kalinina J, Peng J, Ritchie JC, Van Meir EG (2011) Proteomics of gliomas: initia biomarker discovery and evolution of technology. Neuro Oncol 13: 926-942.

36. Freitas M, Malheiros S, Stávale JN, Biassi TP, Zamunér FT, et al. (2013) Expression of cancer/testis antigens is correlated with improved survival in glioblastoma. Oncotarget 4: 636-646.

37. Okada H, Kalinski P, Ueda R, Hoji A, Kohanbash G, et al. (2011) Induction of CD8+ T-cell responses against novel glioma-associated antigen peptides and clinical activity by vaccinations with \{alpha\}-type 1 polarized dendritic cells and polyinosinic-polycytidylic acid stabilized by lysine and carboxymethylcellulose in patients with recurrent malignant glioma. J Clin Oncol 29: 330-336.

38. Terasaki M, Shibui S, Narita Y, Fujimaki T, Aoki T, et al. (2011) Phase I trial of a personalized peptide vaccine for patients positive for human leukocyte antigen-A24 with recurrent or progressive glioblastoma multiforme. J Clin Oncol 29: 337-344.

39. Moffatt S, Cristiano RJ (2006) Uptake characteristics of NGR-coupled stealth $\mathrm{PEI} / \mathrm{pDNA}$ nanoparticles loaded with PLGA-PEG-PLGA tri-block copolymer for targeted delivery to human monocyte-derived dendritic cells. Int J Pharm 321 : 143-54.

40. Parajuli P, Mathupala S, Sloan AE (2004) Systematic comparison of dendritic cell-based immunotherapeutic strategies for malignant gliomas: in vitro induction of cytolytic and natural killer-like T cells. Neurosurgery 55: 1194-1204

41. Xu Q, Liu G, Yuan X, Xu M, Wang H, et al. (2009) Antigen-specific T-cell response from dendritic cell vaccination using cancer stem-like cell-associated antigens. Stem Cells 27: 1734-1740.

42. Hua W, Yao Y, Chu Y, Zhong P, Sheng X, et al. (2011) The CD133+ tumor stemlike cell-associated antigen may elicit highly intense immune responses against human malignant glioma. J Neurooncol 105: 149-157.

43. Harshyne LA, Hooper KM, Andrews EG, Nasca BJ, Kenyon LC, et al. (2014) Glioblastoma exosomes and IGF-1R/AS-ODN are immunogenic stimuli in a translational research immunotherapy paradigm. Cancer Immunol Immunother 64: 299-309.

44. Li Y, Wang LX, Pang P, Cui Z, Aung S, et al. (2011) Tumor-derived autophagosome vaccine: mechanism of cross-presentation and therapeutic efficacy. Clin Cancer Res 17: 7047-7057.

45. Gustafson MP, Knutson KL, Dietz AB (2008) Therapeutic vaccines for malignant brain tumors. Biologics 2: 753-761.

46. Yamanaka R (2009) Dendritic-cell- and peptide-based vaccination strategies for glioma. Neurosurg Rev 32: 265-273.

47. Fujita M, Zhu X, Ueda R, Sasaki K, Kohanbash G, et al. (2009) Effective immunotherapy against murine gliomas using type 1 polarizing dendritic cellssignificant roles of CXCL10. Cancer Res 69: 1587-1595. 
Citation: Chao T, Xiaowen W, Zhiqi L, Qi Y, Zixiao Y, et al. (2015) A Systemic Review of Clinical Trials on Dendritic-Cells Based Vaccine Against Malignant Glioma. J Carcinogene Mutagene 6: 222. doi:10.4172/2157-2518.1000222

48. Baral A, Ye HX, Jiang PC, Yao Y, Mao Y (2014) B7-H3 and B7-H1 expression in cerebral spinal fluid and tumor tissue correlates with the malignancy grade of glioma patients. Oncol Lett 8: 1195-1201.

49. Wheeler CJ (2010) Dendritic cell vaccines to combat glioblastoma. Expert Rev Neurother 10: 483-486.

50. Pellegatta S, Poliani PL, Stucchi E, Corno D, Colombo CA, et al. (2010) Intratumoral dendritic cells increase efficacy of peripheral vaccination by modulation of glioma microenvironment. Neuro Oncol 12: 377-388.

51. Okada H (2009) Brain tumor immunotherapy with type-1 polarizing strategies. Ann N Y Acad Sci 1174: 18-23.

52. Maughan CN, Preston SG, Williams GR (2015) Particulate inorganic adjuvants: recent developments and future outlook. J Pharm Pharmacol 67: 426-449.

53. Draube A, Klein-González N, Mattheus S, Brillant C, Hellmich M, et al. (2011) Dendritic cell based tumor vaccination in prostate and renal cell cancer: a systematic review and meta-analysis. PLoS One 6: e18801.

54. Lion E, Smits EL, Berneman ZN, Van Tendeloo VF (2012) NK cells: key to success of DC-based cancer vaccines? Oncologist 17: 1256-1270.

55. Prins RM, Soto H, Konkankit V, Odesa SK, Eskin A, et al. (2011) Gene expression profile correlates with T-cell infiltration and relative survival in glioblastoma patients vaccinated with dendritic cell immunotherapy. Clin Cancer Res 17: 1603-1615.

56. Ghebeh H, Al-Alwan M (2013) Do Cancer Stem Cells have an Immunomodulatory Role Different from the Bulk of Tumor Cells. J Carcinogene Mutagene S14: 003.

57. Avril T, Vauleon E, Tanguy-Royer S, Mosser J, Quillien V (2011) Mechanisms of immunomodulation in human glioblastoma. Immunotherapy 3: 42-44.
58. Jeon H, Vigdorovich V, Garrett-Thomson SC, Janakiram M, Ramagopal UA, et al. (2014) Structure and cancer immunotherapy of the B7 family member B7x. Cell Rep 9: 1089-1098.

59. Cantini G, Pisati F, Mastropietro A, Frattini V, Iwakura Y, et al. (2011) A critical role for regulatory $T$ cells in driving cytokine profiles of Th17 cells and their modulation of glioma microenvironment. Cancer Immunol Immunother 60: 1739-1750.

60. Mirghorbani M, Van Gool S, Rezaei N (2013) Myeloid-derived suppressor cells in glioma. Expert Rev Neurother 13: 1395-1406.

61. Wu A, Wei J, Kong LY, Wang Y, Priebe W, et al. (2010) Glioma cancer stem cells induce immunosuppressive macrophages/microglia. Neuro Oncol 12 $1113-1125$.

62. Kraman M, Bambrough PJ, Arnold JN, Roberts EW, Magiera L, et al. (2010) Suppression of antitumor immunity by stromal cells expressing fibroblast activation protein-alpha. Science 330: 827-830.

63. Nair JR, Carlson LM, Koorella C, Rozanski CH, Byrne GE, et al. (2011) CD28 expressed on malignant plasma cells induces a prosurvival and immunosuppressive microenvironment. J Immunol 187: 1243-1253.

64. He H, Xu J, Warren CM, Duan D, Li X, et al. (2012) Endothelial cells provide an instructive niche for the differentiation and functional polarization of M2-like macrophages. Blood 120: 3152-3162.

65. Moutsopoulos NM, Wen J, Wahl SM (2008) TGF-beta and tumors--an ill-fated alliance. Curr Opin Immunol 20: 234-240.

66. Okada H, Butterfield LH, Hamilton RL, Hoji A, Sakaki M, et al. (2014) Induction of robust type-1 CD8+ T-cell responses in WHO grade II low-grade glioma patients receiving peptide-based vaccines in combination with poly-ICLC. Clin Cancer Res 21: 286-294. 